\title{
Pengembangan Lembar Kerja Peserta Didik (LKPD) Berbasis Software Liveworksheet pada Materi PPKn
}

\author{
Afifah Widiyani, Puri Pramudiani \\ Universitas Muhammadiyah Prof. Dr. HAMKA \\ Afifahwidiyanii@gmail.com
}

\section{Article History}

received 13/7/2021

\begin{abstract}
This study aims to develop the teaching material needed as a support for the achievement of indicators of students' learning outcomes, and to know the feasibility and the response of the students to the use of Student's Worksheets based on liveworksheet software on PPKn subject. The method used in this research was Research and Development (R\&D) using ADDIE development model. At the validation stage, liveworksheet was validated with 2 validators, namely 1 material expert validator and 1 media expert validator. At the implementation stage, liveworksheet software was tested in grade $V$ students in the even semester of 2020-2021 academic year. The results showed that liveworksheet software was feasible with the percentage of achievements was $75 \%$ according to media expert, and $91,75 \%$ according to material expert. The test results of the students showed the percentage of $73,52 \%$ with good criteria. Therefore, it can be concluded that liveworksheet software on PPKn subject in sub theme "Rights" is feasible and interesting to be used as evaluation Irarning media for fifth grade students.
\end{abstract}

Keywords: Distance Learning; LKPD; Software; Liveworksheet

\begin{abstract}
Abstrak
Penelitian ini bertujuan untuk mengembangkan bahan ajar sebagai pendukung tercapainya indikator hasil belajar siswa dan untuk mengetahui kelayakan, dan respon peserta didik terhadap penggunaan Lembar Kerja Peserta Didik (LKPD) berbasis software liveworksheet pada materi PPKn. Metode yang digunakan dalam penelitian ini adalah Research and Development (R\&D) dengan model pengembangan ADDIE. Pada tahap validasi, LKPD ini divalidasi dengan 2 validator yakni 1 validator ahli materi dan 1 validator ahli media. Pada tahap implementasi, LKPD berbasis software liveworksheet diuji pada peserta didik kelas V SDN Kebon Kosong 07 Pagi pada semester genap 2020-2021. Hasil penelitian ini menunjukkan bahwa LKPD berbasis software liveworksheet layak dengan presentase capaian sebesar $75 \%$ menurut ahli media, dan $91,75 \%$ menurut ahli materi. Hasil uji coba terhadap peserta didik menunjukkan presentase sebesar $73,52 \%$ dengan kriteria baik. Simpulan dari penelitian LKPD berbasis software liveworksheet pada materi PPKn pada subtema "Hak" adalah layak dan menarik untuk digunakan sebagai media evaluasi pembelajaran bagi siswa kelas $\mathrm{V}$.
\end{abstract}

Kata kunci: Pembelajaran Jarak Jauh, LKPD, Software, Liveworksheet 


\section{PENDAHULUAN}

Belajar adalah suatu proses untuk memperoleh motivasi dalam pengetahuan, keterampilan, kebiasaan dan tingkah laku (R.Gagne dalam Khuluqo, 2017). Tujuan dilakukannya proses belajar adalah terjadinya perubahan, baik dari aspek kognitif maupun aspek sikap dari individu tersebut setelah dilakukannya proses belajar. Proses belajar tentu sangat berkaitan dengan proses pembelajaran. Winkel dalam Khuluqo (2017), mengartikan pembelajaran sebagai seperangkat tindakan yang dirancang untuk memperhitungkan kejadian - kejadian eksternal yang berperan terhadap rangkaian kejadian internal yang berlangsung di dalam diri peserta didik. Pada masa pandemi saat ini tentu sangat berdampak terhadap pola hidup yang biasa kita jalani. Hal ini berdampak pula terhadap proses belajar dan pembelajaran yang ada di sekolah. Semua dilakukan secara online, guru harus beradaptasi dengan berbagai hal baru untuk melaksanakan Pembelajaran Jarak Jauh (PJJ). Pembelajaran jarak jauh merupakan pembelajaran yang digunakan tanpa hadir secara fisik antara peserta didik dan pengajar di sekolah (Setiawan, 2020).

Sudah hampir satu tahun pandemi ini berlangsung, pembelajaran masih dilakukan secara jarak jauh. Dalam proses belajar dan pembelajaran salah satu hasil yang akan didapat dari proses tersebut adalah tercapai atau tidaknya indikator hasil belajar siswa. Agar hal tersebut tercapai diperlukan suatu bahan ajar sebagai pendukung tercapainya indikator hasil belajar siswa, bahan ajar tersebut diantaranya adalah Lembar Kerja Peserta Didik (LKPD). Sesuai dengan Pedoman Umum Pengembangan Bahan Ajar yang disusun oleh Depdiknas lembar kerja peserta didik (student worksheet) dapat diartikan berupa lembaran - lembaran berisi tugas yang harus dikerjakan oleh peserta didik (Prastowo dalam Andriyani et al., 2020). Lembar Kerja Peserta Didik (LKPD) sangat diperlukan untuk mengetahui keberhasilan peserta didik dalam memahami dan menguasai ilmu yang diberikan (Widodo, 2017).

Dalam proses Pembelajaran Jarak Jauh (PJJ) saat ini tentu membutuhkan multimedia interaktif untuk lebih menarik perhatian peserta didik dan memotivasi peserta didik dalam mengikuti proses pembelajaran. Multimedia dapat dilihat sebagai alat atau perangkat pembelajaran dan komunikasi, mengingat dengan multimedia kita dapat belajar sebuah topik, materi, dan konten belajar. Tujuan umum penggunaan multimedia dalam pendidikan menurut Andresen \& Brink (2013 : 3) adalah untuk mengkonstruksi pengetahuan yang bermakna dan dapat dimengerti, mengkonstruksi pengetahuan yang dapat diaplikasikan, dan mengkonstruksi pengetahuan tentang belajar, kompetensi yang penting ini memungkinkan peserta didik menjadi ahli dalam proses belajar secara mandiri (Rusli, M., Hermawan, D., dan Supuwiningsih, 2017).

Berdasarkan hasil observasi yang dilakukan di kelas V SDN Kebon Kosong 07 Pagi, bahwa proses belajar dan Pembelajaran Jarak Jauh (PJJ) tersebut masih menggunakan media yang umum digunakan dari awal masa pandemi, dimana guru menjelaskan materi menggunakan aplikasi zoom meeting atau google meet namun tidak setiap hari hal ini dilakukan, setelah itu guru membagikan Lembar Kerja Peserta Didik (LKPD) kepada peserta didik melalui aplikasi google classroom atau whatsapp. Kemudian peserta didik mengirimkan kembali tugas yang diberikan guru melalui aplikasi google classroom atau whatsapp. Dari hasil pengamatan yang dilakukan maka terdapat kemungkinan lama kelamaan akan menimbulkan rasa jenuh. Melihat fenomena tersebut, peneliti merasa perlu melakukan pengembangan dalam penggunaan media pembelajaran yang lebih interaktif atau dapat disebut sebagai multimedia interaktif, untuk mendukung keefektifan belajar dan pembelajaran secara online demi tercapainya pembelajaran yang bermakna bagi peserta didik di SDN Kebon Kosong 07 Pagi, dan sesuai dengan tujuan umum penggunaan multimedia yang telah dijelaskan sebelumnya. Dengan demikian penggunaan software liveworksheet diharapkan dapat meningkatkan motivasi dan minat belajar peserta 
didik. Software liveworksheet adalah aplikasi yang dapat mengubah lembar kerja tradisional yang dapat dicetak berupa (dokumen, pdf, dan jpg) menjadi latihan online interaktif karena dapat memuat video, gambar, maupun audio(Liveworksheet, n.d.).

Berdasarkan permasalahan yang telah dikemukakan di atas, dapat diketahui bahwa LKPD dengan menggunakan software liveworksheet memiliki potensi besar untuk dikembangkan sebagai salah satu media pembelajaran. Oleh karena itu, peneliti mengembangkan LKPD berbasis software liveworksheet pada mata pelajaran PPKn kelas $\mathrm{V}$ tema 6 subtema 1 pembelajaran 3 mengenai "Hak". Peneliti memfokuskan penelitian ini pada pengembangan Lembar Kerja Peserta Didik (LKPD) berbasis software liveworksheet dalam materi PPKn subtema "Hak. Peneliti mengambil mata pelajaran PPKn karena pembelajaran PPKn dirancang untuk memperkuat keterampilan bersikap dan kemampuan intelektual seseorang dalam menjelaskan, menganalisis, mengevaluasi, dan mengambil keputusan atau mempertahankan pemahamannya tentang isu - isu publik ( Branson dalam Ahmad et al., 2017). Hal ini bertujuan agar terciptanya warganegara yang baik dan semua itu berawal dari pendidikan dasar. Untuk mencapai tujuan pembelajaran PPKn tersebut, maka diperlukan kemampuan dalam merancang proses pembelajaran yang bermutu (Fathurrahman et al., 2020). Setiap pembelajaran yang berlangsung diharapkan dapat mendorong peserta didik untuk mencermati, menanya, mengumpulkan informasi, mengartikan dan menyampaikan pelajaran(Abidin \& Utami, 2021).

Penelitian yang pernah dilakukan oleh Andriyani et al., (2020) mengenai penerapan model problem based learning berbantuan LKPD liveworksheet untuk meningkatkan keaktifan mental peserta didik, dengan menggunakan Penelitian Tindakan Kelas (PTK) yang dilakukan sebanyak 2 siklus menunjukkan peningkatan keaktifan mental belajar peserta didik dengan rata - rata $71,91 \%$ pada siklus 1 menjadi $86,27 \%$ pada siklus 2. Dengan demikian, hasil yang didapat menunjukkan bahwa melalui model pembelajaran problem based learning berbantuan LKPD liveworksheet dapat meningkatkan keaktifan mental peserta didik. Hal ini dapat dilihat dari antusias peserta didik selama mengikuti proses pembelajaran, kemandirian peserta didik dalam mengerjakan LKPD serta kepercayaan diri peserta didik dalam mengemukakan pendapatnya, dan meningkatkan rasa ingin tahu peserta didik.

Hasil kegiatan penelitian tersebut menjadi acuan peneliti untuk mengembangkan LKPD berbasis software liveworksheet pada materi PPKn dengan keunggulan dapat meningkatkan keaktifan mental peserta didik, karena dapat mendukung salah satu tujuan pembelajaran PPKn untuk membentuk karakter peserta didik menjadi individu dan warganegara yang baik, serta lebih termotivasi untuk mengikuti pembelajaran PPKn.

Tujuan penelitian ini adalah untuk mengembangkan, mengetahui kelayakan, dan respon peserta didik terhadap penggunaan Lembar Kerja Peserta Didik (LKPD) berbasis software liveworksheet pada materi PPKn "Hak" bagi siswa kelas V SDN Kebon Kosong 07 Pagi. Untuk mengetahui ketercapaian tujuan penelitian tersebut, peneliti menggunakan 3 aspek penilaian yakni kognitif, afektif dan konatif. Menurut Bimo Walgito dalam Hardini (2015) aspek kognitif yakni berkaitan dengan bagaimana seseorang memahami obyek, aspek afektif yakni berhubungan dengan rasa senang atau tidak senang terhadap obyek, sedangkan aspek konatif yakni berhubungan dengan seseorang berperilaku terhadap obyek.

\section{METODE}

Penelitian ini dilaksanakan di SDN Kebon Kosong 07 Pagi. Metode penelitian yang digunakan pada penelitian ini adalah metode penelitian pengembangan Research and Development (R\&D).Menurut Sugiyono dalam Haryati (2012) metode penelitian 
dan pengembangan merupakan penelitian yang dapat digunakan untuk melahirkan produk, serta menguji keefektifan produk. Dalam proses penelitian ini menggunakan prosedur pengembangan ADDIE, model ini terdiri dari lima langkah, yakni : (1) analisis, (2) peracangan, (3) pengembangan, (4) penerapan dan (5) evaluasi (Tegeh \& Kirna, 2013). Teknik pengumpulan data yang digunakan berupa observasi, konsultasi dengan wali kelas, dan angket, teknik analisis data menggunakan rating scale dengan skor 1 sampai 4. Rating scale adalah bentuk survei tertutup yang dapat digunakan untuk mewakili tanggapan responden dari pertanyaan pilihan ganda, rating scale digunakan untuk mengumpulkan data dalam penelitian tertentu (Hayati, 2021). Adapun tahapan penelitian dapat dilihat pada gambar 1

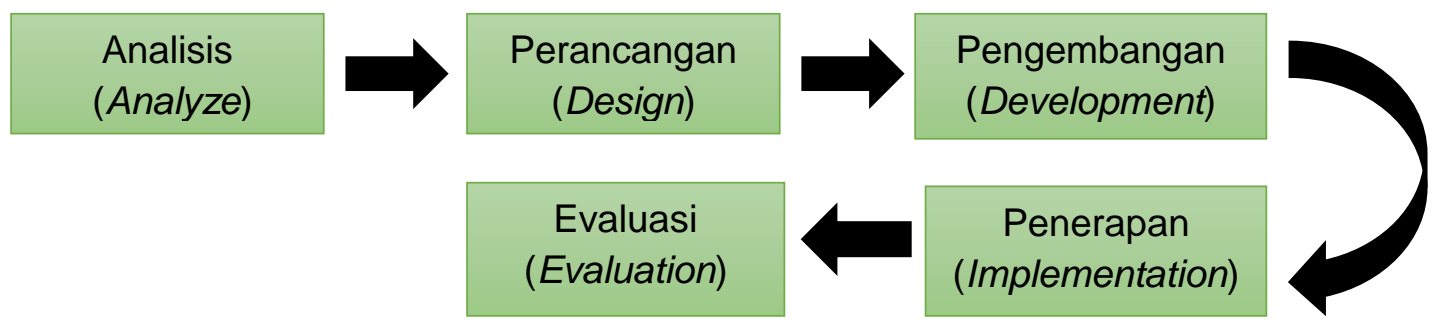

\section{Gambar 1. Langkah Pengembangan Model Research and Development (R \&D) menurut ADDIE (Pratama \& Saregar, 2019).}

\section{HASIL DAN PEMBAHASAN}

Sebelum merancang LKPD terlebih dahulu dikumpulkan sumber - sumber relevan diantaranya silabus, buku guru, buku siswa, dan internet terutama jurnal sebagai bahan referensi dalam membuat LKPD, juga berdiskusi dengan wali kelas. Kemudian disusun indikator dan isi LKPD berbasis software liveworksheet yaitu petunjuk penggunaan, rangkuman materi, kegiatan atau tugas. Setelah LKPD berbasis software liveworksheet memenuhi semua indikator, selanjutnya adalah membuat desain cover, background dan video pembelajaran menggunakan Microsoft Word dan Canva. Microsoft Word adalah aplikasi untuk mengolah data yang dapat di gunakan untuk mendukung kinerja yang berhubungan dengan dokumen, teks, atau tulisan, contohnya untuk membuat makalah, jurnal, laporan, dan lain sebagainya (Sumberpengertian.id, 2020). Hasilnya dapat disimpan dalam bentuk softcopy atau hardcopy. Microsoft Word juga dapat digunakan untuk memuat gambar, tabel, word art , penomoran halaman dan memiliki beragam format keluaran file mulai dari text sampai format pdf (Putra, 2020). Sedangkan Canva diperlukan untuk membuat video pemebelajaran, Canva merupakan alat bantu desain dan publikasi online yang berguna untuk membuat desain apapun dan mempublikasikannya dimanapun. Aplikasi ini diluncurkan sejak tahun 2013 (Canva, n.d.). LKPD berbasis software liveworksheet dapat diakses melalui link https://www.liveworksheets.com/yn2029019la atau dapat dilihat pada gambar dibawah ini : 


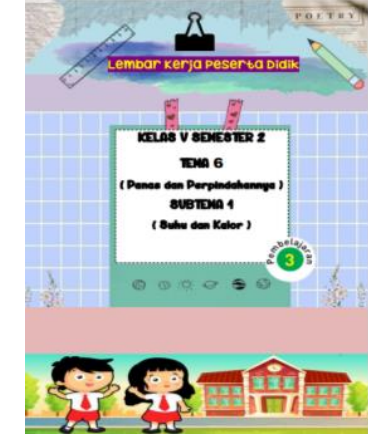

Gambar 2. Cover LKPD

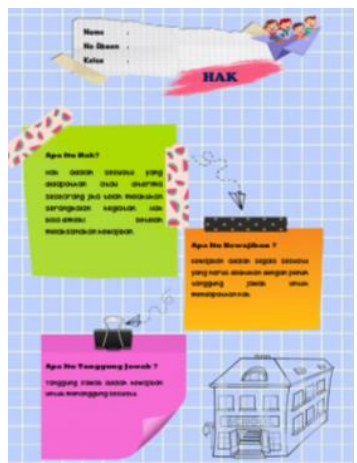

Gambar 4. Rangkuman Materi

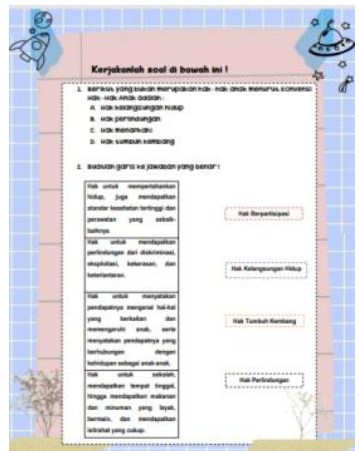

Gambar 6. Kegiatan atau Tugas

\section{Hak-Hak Anak}

Kelas 5

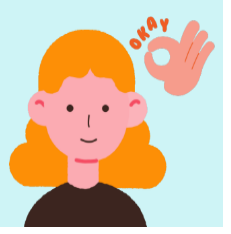

Gambar 8. Cover video "Hak Anak"

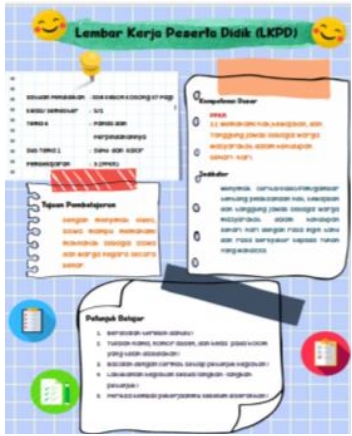

Gambar 3. Info Pendukung dan Petunjuk belajar

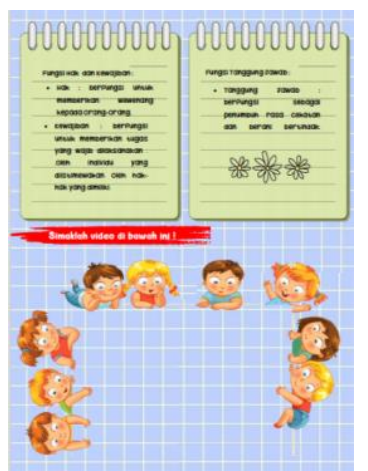

Gambar 5. Rangkuman Materi dan Video Pembelajaran

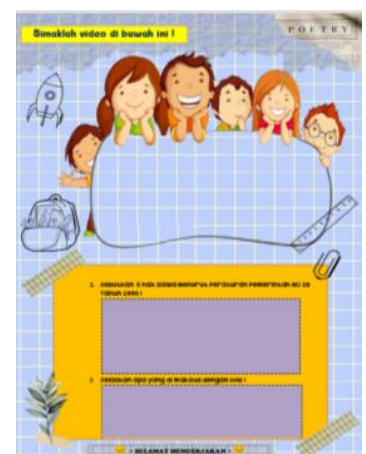

Gambar 7. Video Pembelajaran dan Tugas

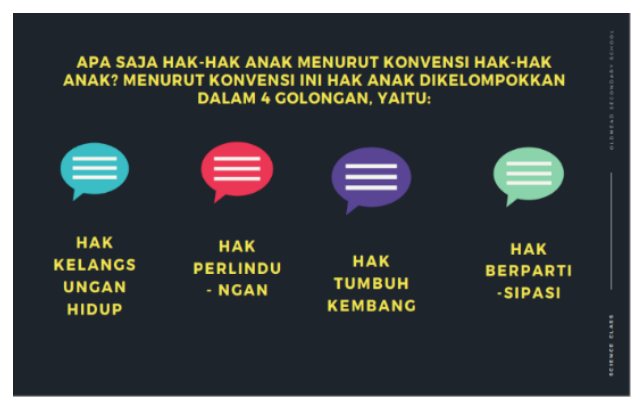

Gambar 9. Materi yang Akan Disampaikan 


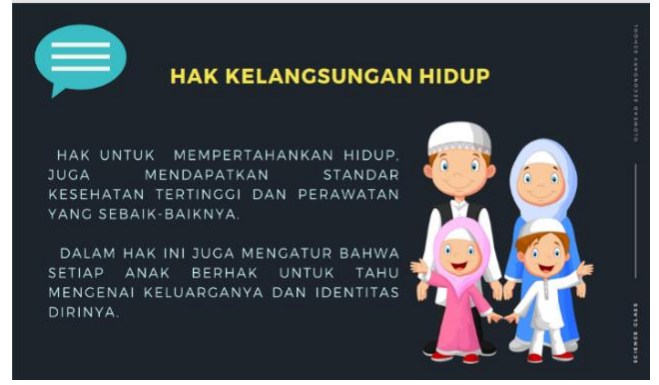

Gambar 10. Tampilan Narasi

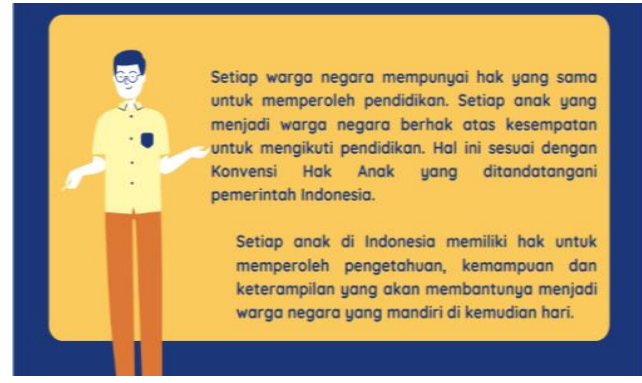

Gambar 12. Tampilan Narasi

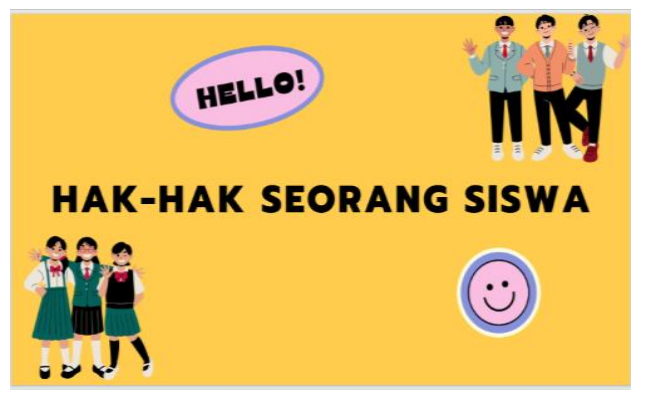

Gambar 11. Cover Video "Hak Siswa"

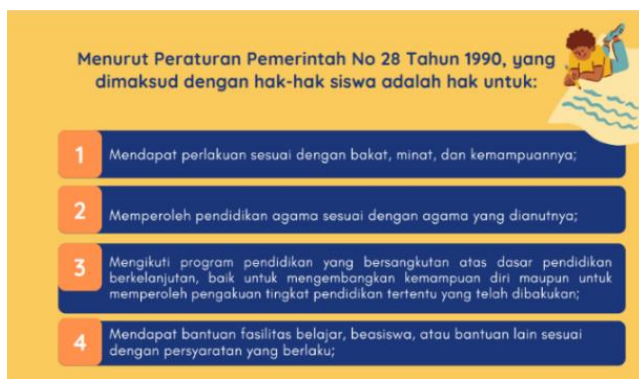

Gambar 13. Tampilan Penjelasan

$\%$ Tanggapan $=\frac{n}{N} \times 100$

Keterangan:

$$
\begin{array}{ll}
\% & =\text { Persentase Tanggapan } \\
\mathrm{n} & =\text { Jumlah skor kriterium } \\
\mathrm{N} & =\text { Jumlah skor maksimum }
\end{array}
$$

Validasi kelayakan media LKPD berbasis software liveworksheet dalam materi PPKn "Hak" telah mendapatkan penilaian dari ahli materi dan ahli media menggunakan instrumen dengan skor $1-4$ sesuai dengan interval presentase skor hasil dan kriteria interpretasi yang telah ditetapkan sebelumnya, seperti dapat dilihat pada tabel 1

Tabel 1. Kategori Interpretasi Skor Kevalidan

\begin{tabular}{ccc}
\hline Skala Nilai & Skor (\%) & Tingkat Kategori \\
\hline $\mathbf{1}$ & $0-25$ & Sangat tidak baik \\
$\mathbf{2}$ & $26-50$ & Tidak baik \\
$\mathbf{3}$ & $51-75$ & Baik \\
$\mathbf{4}$ & $76-100$ & Sangat baik \\
\hline \multicolumn{3}{l}{ Sumber : (Riduwan dalam Abdurrahman et al., 2015). }
\end{tabular}

Berdasarkan hasil penilaian kelayakan dari para ahli dapat dilihat pada tabel 2

Tabel 2. Penilaian LKPD berbasis software liveworksheet

\begin{tabular}{ccc}
\hline Penilaian & Presentasi Skor Akhir & Kriteria \\
\hline Ahli & $91,75 \%$ & $\begin{array}{c}\text { Sangat } \\
\text { Baik } \\
\text { Materi }\end{array}$ \\
Ahli & $75 \%$ & Baik \\
Media & & \\
\hline
\end{tabular}


Rincian hasil validasi ahli materi dapat dilihat pada Tabel 3

Tabel 3. Hasil validasi materi

\begin{tabular}{cccccc}
\hline Aspek & Jumlah Soal & $\begin{array}{c}\text { Skor } \\
\text { Perolehan }\end{array}$ & $\begin{array}{c}\text { Skor } \\
\text { Maksimal }\end{array}$ & $\%$ & Kategori \\
\hline $\begin{array}{c}\text { Relevansi } \\
\text { Keakuratan }\end{array}$ & 3 & 12 & 12 & 100 & Sangat Baik \\
$\begin{array}{c}\text { Konsep Dasar } \\
\text { Materi }\end{array}$ & 2 & 11 & 12 & 92 & Sangat Baik \\
Keseuaian & 2 & 8 & 8 & 100 & Sangat Baik \\
\hline
\end{tabular}

Validasi kelayakan materi terdiri dari 4 aspek, yakni: (1) Relevansi, (2) Keakuratan, (3) Konsep dasar materi, dan (4) Kesesuaian (Azizah, 2019). Validasi kelayakan materi bertujuan untuk mengetahui kesesuaian antara isi konten media yang dikembangkan dengan kebutuhan siswa. Hasil kelayakan ahli materi menunjukkan LKPD berbasis software liveworksheet memperoleh rata - rata presentase sebesar $91,75 \%$ dengan kriteria sangat baik, aspek yang memiliki presentase tertinggi adalah aspek relevansi dan konsep dasar materi yakni 100\%. Kriteria ini didapat setelah melakukan bimbingan dan revisi oleh ahli materi terlebih dahulu. Ada beberapa saran dari ahli untuk menambahkan materi dan mengubah kalimat dalam materi, menjadi kalimat yang mudah untuk dipahami oleh peserta didik.

Berikut adalah hasil validasi ahli media yang dapat dilihat pada tabel 4

Tabel 4. Hasil validasi media

\begin{tabular}{cccccc}
\hline Aspek & $\begin{array}{c}\text { Jumlah } \\
\text { Soal }\end{array}$ & $\begin{array}{c}\text { Skor } \\
\text { Perolehan }\end{array}$ & $\begin{array}{c}\text { Skor } \\
\text { Maksimal }\end{array}$ & $\%$ & Kategori \\
\hline $\begin{array}{c}\text { Tampilan } \\
\text { Umum }\end{array}$ & 4 & 12 & 16 & 75 & Baik \\
$\begin{array}{c}\text { Tampilan } \\
\text { Khusus }\end{array}$ & 4 & 12 & 16 & 75 & Baik \\
$\begin{array}{c}\text { Penyajian } \\
\text { Media }\end{array}$ & 3 & 9 & 12 & 75 & Baik \\
\hline
\end{tabular}

Sedangkan validasi kelayakan media terdiri dari 3 aspek yakni: (1) Tampilan umum, (2) Tampilan khusus, dan (3) Penyajian media (Azizah, 2019). Validasi ini bertujuan untuk mengetahui kualitas dan keefektifan media yang telah dikembangkan. Hasil kelayakan ahli media menunjukkan LKPD berbasis software liveworksheet memperoleh rata - rata presentase sebesar $75 \%$ dengan kriteria baik. Seluruh aspeknya memiliki presentase yang sama rata yakni $75 \%$. Adapun saran yang diberikan oleh ahli media adalah perhatikan gaya huruf yang digunakan dalam media yakni gaya huruf yang mudah dilihat dari kejauhan, tidak ada tebal tipisnya, dan membuat warna yang lebih kontras. 
Berikut adalah hasil tanggapan peserta didik yang dapat dilihat pada tabel 5

Tabel 5. Hasil tanggapan peserta didik

\begin{tabular}{cccccc}
\hline Aspek & $\begin{array}{c}\text { Jumlah } \\
\text { Soal }\end{array}$ & $\begin{array}{c}\text { Skor } \\
\text { Perolehan }\end{array}$ & $\begin{array}{c}\text { Skor } \\
\text { Maksimal }\end{array}$ & $\%$ & Kategori \\
\hline Kognitif & 10 & 654 & 880 & 74,31 & Baik \\
Afektif & 7 & 411 & 616 & 66,72 & Baik \\
Konatif & 1 & 70 & 88 & 79,54 & $\begin{array}{c}\text { Sangat } \\
\text { Baik }\end{array}$ \\
& & & & & \\
\hline
\end{tabular}

Angket tanggapan peserta didik terdiri dari 3 aspek yakni (1) Aspek kognitif, (2) Aspek Afektif, dan (3) Aspek Konatif. Aspek pertanyaan terkait angket tanggapan peserta didik dikembangkan dari penelitian yang dilakukan oleh Nini (2019). Berdasarkan hasil yang diperoleh dari 22 orang responden, menunjukkan tanggapan yang positif dengan memperoleh rata - rata presentase sebesar $73,52 \%$ dengan kriteria baik dan presentase aspek tertingginya adalah aspek konatif yakni $79,54 \%$. Selaras dengan fungsi Lembar Kerja Peserta Didik (LKPD) menurut pendapat Fitriani et al. (2017) yakni sebagai bahan ajar yang dapat meminimalkan peran guru, namun lebih membuat peserta didik berperan aktif, sebagai petunjuk untuk peserta didik dalam mengerjakan tugas, serta mempermudah pelaksanaan pembelajaran. Menurut Trianto dalam Julianti \& Sumarmin (2018) jenis bahan ajar seperti lembar kerja peserta didik merupakan panduan peserta didik yang dapat dijadikan sebagai panduan untuk melatih pengembangan aspek kognitif serta pedoman untuk semua aspek pembelajaran diantaranya panduan demonstrasi. Pendapat lain dari Sirene S.Y dalam Astra et al., (2015) yang berpendapat bahwa penggunaan LKPD dalam proses pembelajaran dapat meningkatkan hasil belajar peserta didik secara signifikan. Secara umum, peserta didik merespons LKPD berbasis software liveworksheet merupakan sesuatu yang baru. Tampilan LKPD yang menarik dapat mempermudah peserta didik dalam memahami materi. Namun tidak dapat dipungkiri terdapat beberapa peserta didik yang masih sulit untuk mengaplikasikan LKPD berbasis software liveworksheet karena kurang memahami petunjuk penggunaan yang telah diberikan, untuk itu kedepannya peneliti akan lebih menekankan pemahaman mengenai penggunaan LKPD berbasis software liveworksheet kepada peserta didik.

\section{SIMPULAN}

LKPD berbasis software liveworksheet dinyatakan telah memenuhi kriteria kelayakan, dan dapat digunakan sebagai salah satu alternatif penggunaan media dalam pembelajaran peserta didik. Produk ini memiliki keunggulan dibandingkan dengan LKPD lain yakni lebih efisien karena tidak perlu menggunakan kertas, dan lebih efektif karena dapat memuat berbagai jenis latihan seperti drag and drop, join with arrows, pilihan ganda, essay, dan video pembelajaran, sehingga peserta didik tidak merasa bosan dalam mengikuti pembelajaran PPKn dan menarik minat peserta didik untuk mempelajari lebih lanjut materi PPKn. LKPD ini dapat diakses dalam format link serta tidak memiliki batasan tertentu untuk mengaksesnya hanya membutuhkan jaringan internet.

Dari hasil uji validasi yang telah dilakukan oleh ahli materi dan ahli media serta dari respon peserta didik dapat diketahui produk ini memperoleh presentase $75 \%$ 
menurut ahli media dengan kriteria baik, 91,75\% menurut ahli materi dengan kriteria sangat baik, dan hasil uji coba terhadap peserta didik menunjukkan presentase sebesar $73,52 \%$ dengan kriteria baik. Pengembangan LKPD berbasis software liveworksheet dapat dijadikan sarana untuk mempermudah peserta didik dalam memahami materi, terutama untuk mempermudah peserta didik dalam memahami materi PPKn yang sering kali dianggap membosankan.

\section{DAFTAR PUSTAKA}

Abdurrahman, Gardjito, \& R.S, B. (2015). Pengembangan Lembar Kegiatan Siswa Berbasis Penemuan Terbimbing Pada Materi Struktur Dan Fungsi Jaringan Tumbuhan Kelas XI SMA. I(September), 1-8.

Abidin, A., \& Utami, K. B. (2021). Pengembangan Lembar Kerja Peserta Didik (Lkpd) Menggunakan Model Pembelajaran Search, Solve, Create, and Share (Sscs) Terhadap Kemampuan Pemecahan Masalah Matematika Siswa Kelas Xi lis Sma Ekasakti Padang. Jurnal Pendidikan Matematika Ekasakti, 1(1), 9-20.

Ahmad, M., Muchlis, S., Ninawati, M., \& All, A. (2017). Pendidikan Pancasila Kewarganegaraan Ikhtiar Membangun Indonesia Berkemajuan.

Andriyani, N., Hanafi, Y., Safitri, I. Y. B., \& Hartini, S. (2020). Penerapan Model Problem Based Learning Berbantuan Lkpd Live Worksheet Untuk Meningkatkan Keaktifan Mental Siswa Pada Pembelajaran Tematik Kelas Va. Prosiding Pendidikan Profesi Guru, September, 122-130. http://eprints.uad.ac.id/21216/1/12. Novi Andriyani-PGSD \%28122-130\%29.pdf

Astra, I. M., Nasbey, H., \& Muharramah, N. D. (2015). Development of Student Worksheet by using Discovery Learning Approach for Senior High School Student. Tarbiya: Journal of Education in Muslim Society, 2(1), 91-96. https://doi.org/10.15408/tjems.v2i1.1749.

Azizah, Z. F. (2019). Instrumen Angket Validasi Pengembangan Media Fung-Cube Pada Pembelajaran Fungi Untuk Siswa SMA. Journal of Chemical Information and Modeling, 53(9), 1689-1699.

Canva. (n.d.). Memberdayakan dunia untuk mendesain. Retrieved July 12, 2021, from https://www.canva.com/id_id/about/.

Fathurrahman, M., Deni Setiawan, Sukarjo, \& Neni Niswatun Hasanah. (2020). Media Audio Visual Mapel PPKn Materi Hak, Kewajiban, dan Tanggung Jawab sebagai Masyarakat untuk Siswa Kelas V. UNNES Journals, 49(2), 56-61.

Fitriani, N., Gunawan, G., \& Sutrio, S. (2017). Berpikir Kreatif Dalam Fisika Dengan Pembelajaran Conceptual Understanding Procedures (CUPs) Berbantuan LKPD. Jurnal Pendidikan Fisika Dan Teknologi, 3(1), 24. https://doi.org/10.29303/jpft.v3i1.319.

Hardini, N. (2015). Persepsi Guru Terhadap Pembelajaran Tematik Pada Implementasi Ktsp Sd Se- Kecamatan Bayan Kabupaten Purworejo Ditinjau Dari Aspek Kognitif. Universitas PGRI Yogyakarta, 1-6.

Haryati, S. (2012). Sebagai Salah Satu Model Penelitian. Research and Development (R\&D) Sebagai Salah Satu Model Penelitian Dalam Bidang Pendidikan, 37, 1126.

Hayati, R. (2021). Pengertian Rating Scale, Ciri, dan Contohnya. https://penelitianilmiah.com/rating-scale/

Julianti, D. P., \& Sumarmin, R. (2018). The Development of Student Worksheet Based on Scientific Approach on Environmental Pollution Topic For Junior High School Student Grade VII. International Journal of Progressive Science and Technologies (IJPSAT), 10(1), pp 11-18.

Khuluqo, I. E. (2017). Belajar dan Pembelajaran Konsep Dasar, Metode Dan Aplikasi Nilai - Nilai Spiritualitas Dalam Proses Pembelajaran. (1st ed.). Pustaka Pelajar. 
Liveworksheet. (n.d.). Liveworksheet. Liveworksheet.Com. Retrieved July 10, 2021, from https://www.liveworksheets.com/aboutthis_en.asp

Nini, N. . (2019). Respon Siswa Terhadap Pembelajaran Interaktif Berbasis Flash Pada Materi Sel Kelas XI Di SMAN 1 Sandai Kabupaten Ketapang

Pratama, R. A., \& Saregar, A. (2019). Pengembangan Lembar Kerja Peserta Didik (LKPD) Berbasis Scaffolding Untuk Melatih Pemahaman Konsep. Indonesian Journal of Science and Mathematics Education, 2(1), 84-97. https://doi.org/10.24042/ijsme.v2i1.3975

Putra. (2020). Microsoft Word: Pengertian, Sejarah \& Fungsi Ms Word. https://salamadian.com/microsoft-word/

Rusli, M., Hermawan, D., dan Supuwiningsih, N. I. (2017). Multimedia Pembelajaran yang Inovatif. Penerbit Andi.

Setiawan, A. R. (2020). Lembar Kegiatan Literasi Saintifik untuk Pembelajaran Jarak Jauh Topik Penyakit Coronavirus 2019 (Covid-19). Edukatif: Jurnal IImu Pendidikan, 2(1), 28-37.

Sumberpengertian.id. (2020). Pengertian Microsoft Word, Fungsi dan Manfaatnya. https://www.sumberpengertian.id/pengertian-microsoft-word

Tegeh, I. M., \& Kirna, I. M. (2013). Pengembangan Bahan Ajar I Made Tegeh dan I Made Kirna (12 - 26). Issn, 2, 12-16.

Widodo, S. (2017). Pengembangan Lembar Kegiatan Peserta Didik (LKPD) berbasis Pendekatan Saintifik untuk Meningkatkan Keterampilan Penyelesaian Masalah Lingkungan Sekitar Peserta Didik di Sekolah Dasar. JPIS Jurnal Pendidikan IImu Sosial, 26(2), 189-204. http://ejournal.upi.edu/index.php/jpis 